\title{
Formulation and Evaluation of Lactic Acid Bacteria Fermented Brassica juncea (Mustard Greens) Pickle with Cholesterol Lowering Property
}

\author{
Chaiyavat Chaiyasut ${ }^{1}$, Periyanaina Kesika ${ }^{1}$, Sasithorn Sirilun ${ }^{1}$, Sartjin Peerajan ${ }^{2}$, Bhagavathi Sundaram Sivamaruthi ${ }^{1 *}$ \\ ${ }^{1}$ Innovation Center for Holistic Health, Nutraceuticals and Cosmeceuticals, Faculty of Pharmacy, Chiang Mai University, Chiang Mai 50200, Thailand. \\ ${ }^{2}$ Health Innovation Institute, Chiang Mai 50230, Thailand.
}

\section{ARTICLE INFO \\ Article history: \\ Received on: $12 / 07 / 2017$ \\ Accepted on: 11/03/2018 \\ Available online: 29/04/2018}

\section{Key words:}

Lactic acid bacteria,

Pickle, Cholesterol-

lowering property, Sensory

evaluation, Antimicrobial

property, Storage, Stability.

\begin{abstract}
Lactic acid bacteria (LAB) mediated fermented mustard green (MG) pickle was prepared, and the cholesterollowering property of the pickle was evaluated. LAB strains were isolated by a plating method and biochemically characterized. Pickle formula was prepared with a various combination of seasonings. Lactic, and acetic acid content was assessed by high-performance liquid chromatography. Methanol and ethanol contents were estimated by gas chromatography. The antimicrobial property was evaluated by plate assay. Cholesterol content was detected by the o-phthalaldehyde method. About 373 bacterial isolates were isolated. After the selection process (bile and $\mathrm{pH}$ tolerance, bile salt hydrolase activity, biochemical profile, and growth pattern), isolate LAB5 was selected as a starter for pickle formulation. Twenty-seven different pickle formulas were prepared. Lactic acid content increased gradually, whereas acetic acid level decreased in the pickles. The acceptable level of ethanol was observed in pickles after 30 days with no methanol content. Pickles showed antimicrobial activity against tested microbes. Cholesterol level in pickle liquid was reduced significantly. The stability and sensory analysis suggested that pickle formula- 2 was accepted by the healthy volunteers. LAB5 fermented MG pickle could be a functional food to control cholesterol. Additional clinical trial helps to explore the in vivo cholesterol lowering property of the formulated pickle.
\end{abstract}

\section{INTRODUCTION}

Pickling is one of the ancient ways of food preservation, and it was a possible way of preserving the foods, especially seasonal foods, before the invention of modern preservative machines like the refrigerator. It is believed that the beginning of the preparation and usage of pickles in India was about 4 to 5 thousands years ago. The traditional pickles contain salt, oil, and dry chili in prescribed proportions, and the proportions varied on the individual' preferences. Pickle is the good source of antioxidants, probiotics, vitamins (vitamin $\mathrm{C}, \mathrm{A}, \mathrm{K}$, and folate), and minerals (iron, calcium, and potassium). Notably, freshly prepared pickles with leafy vegetables and herbs (coriander, curry

"Corresponding Author

Bhagavathi Sundaram Sivamaruthi, Innovation Center for Holistic

Health, Nutraceuticals and Cosmeceuticals, Faculty of Pharmacy,

Chiang Mai University, Chiang Mai 50200, Thailand.

E-mail:sivasgene@gmail.com, sivamaruthi.b@cmu.ac.th leaves, spinach, parsley, and amaranth), and Decalepis hamiltonii based pickles are considered as one of the health supplements in Asian countries (Organic facts, Health benefits of pickles).

The consumption of an excess amount of pickle leads to hypertension since most of the pickle contains salt as an essential ingredient. Some ecological studies revealed the increased risk of esophageal and gastric cancers among the people with high consumption of pickled food (Yang, 1980; Takezaki et al., 1999). The Chinese people who consumed the pickled food, mostly pickled vegetables, every day in their diet for minimum 9 to 12 months were in high-risk of cancer (Yang, 1980). Mainly, commercialized packed vegetables and meaty pickles facilitate the growth of harmful microbes and capable of producing carcinogenic compounds such as N-nitroso compounds and mycotoxins (Cheng et al., 1981; Zhang et al., 1983; IARC Working Group, 1993; Ren et al., 2012). The carcinogenicity and mutagenicity of pickled vegetables have been proved in vitro (Cheng et al., 1980; Lu et al., 1981). 
Probiotics are live microbes, which when administered in adequate amounts, offer a health benefit on the host. The dairy products (for example yogurt, cottage cheese, sour cream) are the cheap source of probiotics. Alternatively, several types of meat and vegetable products and fruit juices are considered as the best source of probiotic microbes (Sheehan et al., 2007; Martins et al., 2013; Rouhi et al., 2013). The consumption of kimchi and other fermented vegetable products help the host to acquire the lactic acid bacteria (LAB), one of the common probiotic bacteria. Moreover, the naturally fermented foods are sheltered for both harmful and beneficial microbes. So the fermented vegetables or pickle products made with characterized probiotic strain confirms the supplementation of probiotics to the consumers.

Mustard greens (MG) are rich in phenolic compounds, vitamins, and minerals. MG is one of the best low-calorie cruciferous vegetable, extensively used in Thailand as a raw vegetable, or as fermented pickle. The isolation of probiotic bacteria from Thai fermented foods with desirable characters and development of fermented plant beverages were reported previously (Woraharn et al., 2015; Woraharn et al., 2016). The current study was conducted to isolate LAB with cholesterol utilizing property from indigenously prepared fermented Thai foods, and to formulate the MG based pickle with different degree of seasonings (garlic, ginger, and chili). The acceptability of the product by consumers and the stability of the products have also been assessed.

\section{METHODS}

\section{Sample collection and isolation}

The fermented food samples such as fermented soy milk, Thuo-nao, Thuo-mhak, Ab-Thuo (Fermented nuts), fermented soy sauce, Tempeh, miso, nutto, and other fermented beverages that contain plant components were collected from the local market, Chiang Mai, Thailand. The samples were immediately transferred to the laboratory under refrigeration, and lactic acid bacteria were isolated as described previously (Woraharn et al., 2014). The mustard green was selected as the base of the pickle, and fresh mustard green was purchased from local market, Chiang Mai, Thailand.

\section{Bile and $\mathrm{pH}$ tolerance test}

The LAB isolates were cultured in MRS broth with 0.15 to $0.3 \%$ of the bile salt or MRS broth at the $\mathrm{pH}$ of $1,2,3,4,8,9$, and 10 (adjusted using $1 \mathrm{~N} \mathrm{HCl}$ and $5 \mathrm{~N} \mathrm{KOH}$ ) for $18-24 \mathrm{~h}$. Then, the bacterial growth was measured at $660 \mathrm{~nm}$ by spectrophotometer (DTX 880, Beckman Coulter Inc., UK) to detect the growth ability of LAB isolates in the presence of different concentration of bile salt or at various $\mathrm{pH}$ (Menconi et al., 2014).

\section{Carbohydrate, Protein and Lipid utilization test}

Starch agar (Hi-Media, catalog no. M107S), skim milk agar (Hi-Media, catalog no. M763), and tributyrin agar (Hi-Media, catalog no. M157) with $2 \%$ of glycerol tributyrate medium were used to assess the carbohydrate, protein, and lipid utilizing ability of LAB isolates. The single colony of LAB isolates was streaked on the respective media and incubated at $37^{\circ} \mathrm{C}$ for $24 \mathrm{~h}$. After incubation, plates were examined for the clear zone formation around the colonies. The iodine solution was used for the better visualization of clear zones in starch and skim milk agar medium (Cappuccino and Sherman, 2011).

\section{Assessment of cholesterol uptake}

The cholesterol utilizing ability of LAB isolates were measured by the method described previously (Rudel and Morris, 1973; Gilliland et al., 1985). Briefly, the LAB isolates were grown at $37^{\circ} \mathrm{C}$ for $24 \mathrm{~h}$ in MRS broth with $1 \%$ pleuropneumonia-like organism (PPLO) serum fraction, and $0.5 \%(\mathrm{w} / \mathrm{v})$ of bile salt. The cells were harvested by centrifugation for $10 \mathrm{~min}$ at 12,000 rpm, and the level of cholesterol in spent medium and cells was assessed by o-phthalaldehyde method (Rudel and Morris, 1973). To measure the cholesterol content in pickle formulas, $\sim 5 \mathrm{~g}$ of pickle liquids were collected at any point of the fermentation process. The cells and broth were separated by centrifugation. Then, the cholesterol level in pickle broth and cells were assessed as described above.

\section{Evaluation of antimicrobial, biochemical and microscopic properties, and growth of $\mathrm{LAB}$}

The antimicrobial nature of isolated LAB was assessed against Escherichia coli ATCC 25922, Staphylococcus aureus ATCC 25923, Bacillus cereus, Pseudomonas aeruginosa ATCC27853, Candida albicans ATCC 90028 by plate assay (Cappuccino and Sherman, 2011). LAB isolates were examined under the microscope after stained with Gram' stain to determine the shape and arrangements of cells (Cappuccino and Sherman, 2011).

The selected LAB strains were analyzed for the sugar utilization profile using Hi CarbohydrateTM Kit (Hi-Media, Catalog no. KB009A, KB009B1, KB009C) as per the manufacturer' instructions. The generation time and specific growth rate of the $\mathrm{LAB}$ isolates were calculated as described (Todar's online textbook of bacteriology, 2008; Samuel Miller Lab, 2011).

\section{Pickle formulations}

The fresh, clean mustard green was squeezed mechanically. Different concentration $(5,15$, and 30\%) and the ratio of garlic, ginger, and chili was added. The combinations of ingredients were tabulated (Table 1).

Twenty-seven combinations of seasonings (garlic, ginger, and chili) were used with a constant volume of squeezed mustard green and $10 \%$ of LAB starter culture. The pickle formulas were incubated at room temperature for 30 days. The pickle mix without any seasonings and LAB starter (control-1), and another formula with $10 \%$ LAB starter and without seasonings (control-2) were served as control.

\section{Quantification of lactic acid, acetic acid, methanol and ethanol in pickle formulas}

The level of lactic and acetic acids in pickle formulas was assessed by high-performance liquid chromatography (HPLC). Methanol and ethanol contents in pickle formulas were estimated by gas chromatography, as described previously (Peerajan et al., 2016; Chaiyasut et al., 2017a; Chaiyasut et al., 2017b). 
Table 1: The different combinations of seasonings for the preparation of $\mathrm{MG}$ pickle (Factorial design). *Control-1 formula was prepared without seasonings and LAB starter. \# Control-2 formula was prepared with $10 \%$ of LAB starter and without seasonings.

\begin{tabular}{|c|c|c|c|}
\hline \multirow[t]{2}{*}{$\begin{array}{l}\text { Formula } \\
\text { numbers }\end{array}$} & \multicolumn{3}{|c|}{$\begin{array}{c}\text { Amount of Ingredients (\%) (Base: MG extract, Salt (2.50), } \\
\text { water }(\mathbf{2 0} \%) \text {, LAB starter }(\mathbf{1 0} \%))\end{array}$} \\
\hline & Ginger & Garlic & Chili \\
\hline Control-1* & - & - & - \\
\hline Control-1\# & - & - & - \\
\hline 1 & 5 & 5 & 5 \\
\hline 2 & 5 & 5 & 15 \\
\hline 3 & 5 & 5 & 30 \\
\hline 4 & 5 & 15 & 5 \\
\hline 5 & 5 & 15 & 15 \\
\hline 6 & 5 & 15 & 30 \\
\hline 7 & 5 & 30 & 5 \\
\hline 8 & 5 & 30 & 15 \\
\hline 9 & 5 & 30 & 30 \\
\hline 10 & 15 & 5 & 5 \\
\hline 11 & 15 & 5 & 15 \\
\hline 12 & 15 & 5 & 30 \\
\hline 13 & 15 & 15 & 5 \\
\hline 14 & 15 & 15 & 15 \\
\hline 15 & 15 & 15 & 30 \\
\hline 16 & 15 & 30 & 5 \\
\hline 17 & 15 & 30 & 15 \\
\hline 18 & 15 & 30 & 30 \\
\hline 19 & 30 & 5 & 5 \\
\hline 20 & 30 & 5 & 15 \\
\hline 21 & 30 & 5 & 30 \\
\hline 22 & 30 & 15 & 5 \\
\hline 23 & 30 & 15 & 15 \\
\hline 24 & 30 & 15 & 30 \\
\hline 25 & 30 & 30 & 5 \\
\hline 26 & 30 & 30 & 15 \\
\hline 27 & 30 & 30 & 30 \\
\hline
\end{tabular}

\section{Assessment of microbial load in pickles}

The microbial contaminates in pickle formulas were studied by plating the serially diluted pickle samples in specific nutrient media. The samples were plated on plate count agar (total bacterial load), potato dextrose agar (yeast and mold), phenol red egg-yolk kanamycin agar (B. cereus), mannitol salt phenol red egg yolk agar (S. aureus), MacConkey agar, Salmonella-Shigella agar (Salmonella spp.), and cooked meat medium (Clostridium perfringens) and incubated at the optimum temperatures of the respective microbes for $24-48 \mathrm{~h}$. Then the colonies were counted, and the colony forming unit (CFU) were calculated (Pattananandecha et al., 2016).

\section{Sensory evaluation test}

A descriptive ratio profile test was conducted to evaluate the acceptability of the pickle formulas. Twenty healthy volunteers (not restricted with age and gender) were tested with the pickle formula regarding color, taste, odor, and general acceptance. The volunteers were advised to clean their mouth with drinking water, before the taste assessment of each pickle. The opinions were recorded with the scale of $0-1$, and the ideal score was fixed as 1. Then, the average ideal ratio scores were represented as graphs using Microsoft ${ }^{\circledR}$ excel program. The study has been approved by the Ethical Review committee of Faculty of Pharmacy, Chiang Mai University (Ref. No. 26/2015 dated 22 April 2015).

\section{Stability test}

The selected pickle formulas were stored at room temperature for sixty days, followed by an assessment of the LAB content and the acceptability was evaluated by sensory analysis.

\section{Statistical analysis}

The biochemical analysis was performed in triplicates and values are represented as mean $\pm \mathrm{SD}$. The difference among the pickle formulations was assessed by analysis of variance (ANOVA) using statistical SPSS software version 16 (Chicago, SPSS Inc, USA) at the $95 \%$ confidential level $(p<0.05)$.

\section{RESULTS AND DISCUSSION}

A sum of 373 bacterial isolates was isolated from collected fermented food samples. About 274, and 121 isolates showed tolerance to $0.15 \%$, and $0.30 \%$ bile salt, respectively. All the isolates were tested for $\mathrm{pH}$ tolerance, and about 197 isolates were found to be grown in the $\mathrm{pH}$ range of 1-4, 8, and 9. Among 197 strains, 47, 34, and 21 isolates were able to utilize protein, carbohydrate, and both, respectively. The lipid utilizing property and bile salt hydrolase (BSH) activity of selected 21 strains were evaluated. Two isolates (coded as LAB3, and LAB5) were confirmed with both lipids utilizing property and BSH activity (Table 2).

Several reports explained the anti-microbial property of LAB isolated from fermented foods, which is attributed to the production of antimicrobial compounds such as bacteriocin by $L$. lactis BH5, L. citreum GJ7 (Hur et al., 2000; Chang et al., 2007), pediocin by $P$. pentosaceus (Shin et al., 2008), and nisin. Thus, the antimicrobial activity of LAB3 and LAB5 were assessed. Both the strains actively suppressed the growth of $S$. aureus, B. cereus, and mild activity was observed against $P$. aeruginosa, E. coli, and $C$. albicans (Table 3). 
Table 2: The basic characteristics of lactic acid bacteria (LAB) isolated from common Thai fermented foods.

\begin{tabular}{|c|c|c|c|}
\hline S. No. & Particulars & Amount (No.) & Explanations \\
\hline 1 & Total LAB isolates & 373 & - \\
\hline \multirow[t]{2}{*}{2} & Bile salt tolerance & 274 & $0.15 \%$ of bile salt \\
\hline & & 121 & $\begin{array}{c}\text { Both } 0.15 \text { and } 0.30 \% \text { of } \\
\text { bile salt }\end{array}$ \\
\hline \multirow[t]{5}{*}{3} & $\mathrm{pH}$ tolerance & $279(\sim 75 \%)$ & Growth at $\mathrm{pH} 2-4$ \\
\hline & & $164(\sim 43.9 \%)$ & Growth at $\mathrm{pH} 1-4$ \\
\hline & & $161(\sim 43 \%)$ & Growth at $\mathrm{pH} 1-4,8$ \\
\hline & & $197(\sim 52.8 \%)^{*}$ & Growth at $\mathrm{pH} 1-4,8,9$ \\
\hline & & $82(\sim 21.9 \%)$ & Growth at $\mathrm{pH} 1-4,8,9,10$ \\
\hline 4 & Protein utilization & 47 & $\begin{array}{l}\text { Growth in skim milk agar } \\
\text { medium }\end{array}$ \\
\hline 5 & $\begin{array}{l}\text { Carbohydrate } \\
\text { utilization }\end{array}$ & 34 & $\begin{array}{l}\text { Growth in starch agar } \\
\text { medium }\end{array}$ \\
\hline 6 & $\begin{array}{c}\text { Protein \& } \mathrm{CHO} \\
\text { utilization }\end{array}$ & 21 & $\begin{array}{l}\text { Growth in both skim milk } \\
\text { and starch agar medium }\end{array}$ \\
\hline 7 & Digestion of lipid & 2 & $\begin{array}{l}\text { Growth in tributyrin agar } \\
\text { medium }\end{array}$ \\
\hline 8 & $\begin{array}{c}\text { Bile salt hydrolase } \\
\text { Activity }\end{array}$ & 2 & $\begin{array}{c}\text { Growth in taurodeoxycho- } \\
\text { lic acid (TDCA) medium; } \\
\text { Sample code: LAB3, and } \\
\text { LAB5 }\end{array}$ \\
\hline
\end{tabular}

*197 isolates were further subjected to protein, carbohydrate, and lipid utilization study.

Table 3: The anti-bacterial nature of selected LAB isolates.

\begin{tabular}{cccccc}
\hline $\begin{array}{c}\text { Sample } \\
\text { code }\end{array}$ & $\begin{array}{c}\text { E. coli } \\
\text { ATCC 25922 }\end{array}$ & $\begin{array}{c}\text { S. aureus } \\
\text { ATCC 25923 }\end{array}$ & B. cereus & P. aeruginosa & C. albicans \\
\hline LAB3 & ++ & +++ & +++ & ATCC 27853 & ATCC 90028 \\
LAB5 & ++ & +++ & +++ & ++ & + \\
\hline
\end{tabular}

Note: + denotes inhibition zone of $<7 \mathrm{~mm}$; ++ denotes inhibition zone of 7-9 $\mathrm{mm}$; +++ denotes inhibition zone of $\geq 10 \mathrm{~mm}$.

The results of biochemical and microscopic observations suggested that both the isolates are identical strains of the LAB. Whereas, the generation time and specific growth rate of both the strains were found to be varied (Table 4). The relatively fast-growing strain, LAB5, was selected for the preparation of fermented pickle with the cholesterol-lowering property.

The traditional fermented plant foods, for example, kimchi, are seasoned with red pepper powder, garlic, ginger, green onion, and salts. The presence of bioactive seasoning compounds and microbial constituents in the fermented food make them as a functional food with antioxidant, antidiabetic, and anti-obesity properties (Shin et al., 2016). The fermented garlic is considered as a functional food with better biological activities, such as antioxidant activity (Li et al., 2017). The anti-obesity property of Lactobacillus-mediated fermented garlic extract was attributed to the suppression of adipogenesis by downregulating the mRNA and proteins that are involved in lipogenesis (Lee et al., 2016). Garlic fermented with Monascus pilosus decreased triglyceride and cholesterol in serum with no adverse effects in normal to mildly hyperlipidemic individuals (Higashikawa et al.,
2012). Hypercholesterolemia initiates the atherogenic process; but, chronic inflammation also promotes atherogenesis. Thus, to prevent the atherogenesis, $20 \%$ of ginger was used in Monascus spp. fermented food, which enhances the anti-inflammatory property of the food (Chen et al., 2010). Thus, in the present study MG pickles were formulated with various concentration and the ratio of seasonings (garlic, ginger, and chili), and were incubated for 30 days (Table 1 ).

Table 4: The microscopic, biochemical, and growth observations of selected LAB strains.

\begin{tabular}{|c|c|c|}
\hline S. No. & Tests/Observations & LAB3 and LAB5 \\
\hline 1 & Shape & Bacillus \\
\hline 2 & Gram straining & + \\
\hline 3 & Catalase test & - \\
\hline 4 & Gas from glucose & - \\
\hline 5 & Growth at $15 / 45^{\circ} \mathrm{C}$ & $+/-$ \\
\hline \multicolumn{3}{|c|}{ Sugar utilization } \\
\hline 6 & Amygdalin & + \\
\hline 7 & Arabinose & + \\
\hline 8 & Cellobiose & + \\
\hline 9 & Esculin & + \\
\hline 10 & Fructose & + \\
\hline 11 & Galactose & + \\
\hline 12 & Glucose & + \\
\hline 13 & Lactose & + \\
\hline 14 & Maltose & + \\
\hline 15 & Mannitol & + \\
\hline 16 & Raffinose & + \\
\hline 17 & Rhamnose & - \\
\hline 18 & Ribose & + \\
\hline 19 & Sorbitol & + \\
\hline 20 & Sucrose & + \\
\hline 21 & Trehalose & + \\
\hline \multicolumn{3}{|l|}{ Growth } \\
\hline \multirow[t]{2}{*}{22} & Generation time & LAB3: $58.85 \mathrm{~min}$ \\
\hline & & LAB5: $50.66 \mathrm{~min}$ \\
\hline \multirow[t]{2}{*}{23} & Specific growth rate $(\mathrm{mu})$ & LAB3: $0.75 \mathrm{~h}^{-1}$ \\
\hline & & LAB5: $0.82 \mathrm{~h}^{-1}$ \\
\hline
\end{tabular}

The formation of organic acids like lactic and acetic acids during the fermentation process is due to the hydrolysis, biochemical, and microbial metabolism (Chaiyasut et al., 2017a). The concentration of lactic and acetic acids in pickles were assessed at two-time points (day 0 and 30). The lactic acid level of all formulas was found to be increased after 30 days of fermentation when compared to that of the day 0 . Notably, formulas 1,2 , and 3 showed the relatively high concentration of lactic acid after 30 days of fermentation $(0.85,0.82$, and $0.81 \mathrm{~g} / 100 \mathrm{ml}$, respectively) (Table 5).

The presence of LAB starter culture increases the concentration of lactic acids in pickles. At the same time, the level of acetic acid was significantly low in formulas 1,2 , and $3(0.032$, 0.034 , and $0.035 \mathrm{~g} / 100 \mathrm{ml}$, respectively) compared to that of the 
control and other pickle formulas (Table 6). The concertation of lactic and acetic acids in all the pickled formulas are in an acceptable level for human consumption. Whereas, formulas 1, 2, and 3 are considered as best among the tested samples.

Table 5: The amount of lactic acid in pickle formulations at different time points. $\mathrm{a}-\mathrm{j}$ indicates the significant difference among the samples $(\mathrm{p}<0.05)$.

\begin{tabular}{|c|c|c|c|c|c|}
\hline \multirow{2}{*}{ Formula No. } & \multicolumn{2}{|c|}{ Lactic acid $(\mathrm{g} / 100 \mathrm{ml})$} & \multirow{2}{*}{ Formula No. } & \multicolumn{2}{|c|}{ Lactic acid $(\mathrm{g} / 100 \mathrm{ml})$} \\
\hline & Day 0 & Day 30 & & Day 0 & Day 30 \\
\hline Control-1 & $0.00^{\mathrm{a}}$ & $0.2^{\mathrm{a}}$ & 14 & $0.06^{\mathrm{gh}}$ & $0.60^{\text {efgh }}$ \\
\hline Control-2 & $0.06^{\mathrm{gh}}$ & $0.5^{\mathrm{b}}$ & 15 & $0.05^{\mathrm{efg}}$ & $0.59^{\text {defg }}$ \\
\hline 1 & $0.05^{\mathrm{fgh}}$ & $0.85^{1}$ & 16 & $0.03^{\mathrm{bc}}$ & $0.58^{\text {cde }}$ \\
\hline 2 & $0.07^{\mathrm{i}}$ & $0.82^{\mathrm{k}}$ & 17 & $0.04^{\mathrm{cd}}$ & $0.58^{\text {cde }}$ \\
\hline 3 & $0.04^{\mathrm{cd}}$ & $0.81^{\mathrm{k}}$ & 18 & $0.04^{\mathrm{cd}}$ & $0.57^{\mathrm{cd}}$ \\
\hline 4 & $0.07^{\mathrm{i}}$ & $0.61^{\text {fghi }}$ & 19 & $0.05^{\mathrm{def}}$ & $0.56^{\mathrm{c}}$ \\
\hline 5 & $0.04^{\mathrm{de}}$ & $0.62^{\mathrm{ij}}$ & 20 & $0.06^{\mathrm{gh}}$ & $0.61^{\text {fghi }}$ \\
\hline 6 & $0.06^{\mathrm{gh}}$ & $0.61^{\text {fghi }}$ & 21 & $0.06^{\mathrm{gh}}$ & $0.62^{\text {ghij }}$ \\
\hline 7 & $0.03^{\mathrm{b}}$ & $0.62^{\mathrm{hij}}$ & 22 & $0.05^{\text {fgh }}$ & $0.58^{\text {cde }}$ \\
\hline 8 & $0.04^{\mathrm{cd}}$ & $0.63^{\mathrm{ij}}$ & 23 & $0.04^{\mathrm{de}}$ & $0.61^{\text {ghi }}$ \\
\hline 9 & $0.04^{\mathrm{cd}}$ & $0.62^{\text {ghij }}$ & 24 & $0.05^{\mathrm{efg}}$ & $0.60^{\text {efgh }}$ \\
\hline 10 & $0.06^{\mathrm{gh}}$ & $0.60^{\text {defg }}$ & 25 & $0.06^{\mathrm{hi}}$ & $0.49^{b}$ \\
\hline 11 & $0.05^{\text {fgh }}$ & $0.64^{\mathrm{i}}$ & 26 & $0.04^{\mathrm{de}}$ & $0.48^{b}$ \\
\hline 12 & $0.03^{\mathrm{b}}$ & $0.58^{\text {cde }}$ & 27 & $0.05^{\text {fgh }}$ & $0.48^{b}$ \\
\hline 13 & $0.07^{\mathrm{hi}}$ & $0.59^{\text {def }}$ & & & \\
\hline
\end{tabular}

Table 6: The amount of acetic acid in pickle formulations at different time points. a-h indicates the significant difference among the samples $(\mathrm{p}<0.05)$.

\begin{tabular}{|c|c|c|c|c|c|}
\hline \multirow{2}{*}{ Formula No. } & \multicolumn{2}{|c|}{ Acetic acid $(\mathrm{g} / 100 \mathrm{ml})$} & \multirow{2}{*}{ Formula No. } & \multicolumn{2}{|c|}{ Acetic acid $(\mathrm{g} / 100 \mathrm{ml})$} \\
\hline & Day 0 & Day 30 & & Day 0 & Day 30 \\
\hline Control-1 & 0 & $0.055^{\mathrm{h}}$ & 14 & 0 & $0.050^{\mathrm{fg}}$ \\
\hline Control-2 & 0 & $0.051^{\text {fgh }}$ & 15 & 0 & $0.053^{\text {gh }}$ \\
\hline 1 & 0 & $0.032^{\mathrm{a}}$ & 16 & 0 & $0.051^{\text {fgh }}$ \\
\hline 2 & 0 & $0.034^{\mathrm{a}}$ & 17 & 0 & $0.049^{\text {ef }}$ \\
\hline 3 & 0 & $0.035^{\mathrm{a}}$ & 18 & 0 & $0.042^{\text {bcd }}$ \\
\hline 4 & 0 & $0.042^{\mathrm{bcd}}$ & 19 & 0 & $0.041^{\mathrm{bc}}$ \\
\hline 5 & 0 & $0.045^{\mathrm{cd}}$ & 20 & 0 & $0.040^{\mathrm{b}}$ \\
\hline 6 & 0 & $0.043^{\text {bcd }}$ & 21 & 0 & $0.043^{\text {bcd }}$ \\
\hline 7 & 0 & $0.046^{\mathrm{de}}$ & 22 & 0 & $0.041^{\mathrm{bc}}$ \\
\hline 8 & 0 & $0.042^{\mathrm{bc}}$ & 23 & 0 & $0.041^{\mathrm{bc}}$ \\
\hline 9 & 0 & $0.050^{\mathrm{fg}}$ & 24 & 0 & $0.042^{\text {bcd }}$ \\
\hline 10 & 0 & $0.051^{\mathrm{fgh}}$ & 25 & 0 & $0.043^{\text {bcd }}$ \\
\hline 11 & 0 & $0.042^{\text {bcd }}$ & 26 & 0 & $0.051^{\text {fgh }}$ \\
\hline 12 & 0 & $0.046^{\mathrm{de}}$ & 27 & 0 & $0.040^{\mathrm{b}}$ \\
\hline 13 & 0 & $0.042^{\text {bcd }}$ & & & \\
\hline
\end{tabular}

The ethanol and methanol are primary alcohols in the fermentation process. Maintaining an acceptable level of ethanol and methanol in the processed food, especially fermented food is critical. The acceptable range of ethanol in the fermented product is less than 5\%, and methanol is acceptable up to $240 \mathrm{ppm}$ in fermented foods as per Thai Community Product Standard (TCPS) (Chaiyasut et al., 2017b). The kinetic analysis showed that the ethanol level was slightly increased over the period in pickles and reached to the maximum of $0.870 \%$ in formula 20 . Whereas, the methanol was not detected in all the pickles including controls (Tables 7 and 8). So the pickle formulations are safe regarding alcohol content.

Table 7: The amount of methanol in pickle formulations at different time points. $\mathrm{a}-\mathrm{k}$ indicates the significant difference among the samples $(\mathrm{p}<0.05)$.

\begin{tabular}{|c|c|c|c|c|c|}
\hline \multirow{2}{*}{$\begin{array}{c}\text { Formula } \\
\text { No. }\end{array}$} & \multicolumn{2}{|c|}{ Methanol (ppm) } & \multirow[b]{2}{*}{ Formula No. } & \multicolumn{2}{|c|}{ Methanol (ppm) } \\
\hline & Day 0 & $\begin{array}{c}\text { Days } 7, \\
15 \text {, and } 30\end{array}$ & & Day 0 & $\begin{array}{c}\text { Days } 7,15, \\
\text { and } 30\end{array}$ \\
\hline Control-1 & $18.2969^{\mathrm{abc}}$ & 0 & 14 & $19.0002^{\mathrm{abcd}}$ & 0 \\
\hline Control-2 & $19.4263^{\text {bdef }}$ & 0 & 15 & $20.4100^{\text {efgh }}$ & 0 \\
\hline 1 & $22.4231^{\mathrm{ij}}$ & 0 & 16 & $18.0341^{\mathrm{a}}$ & 0 \\
\hline 2 & $19.2345^{\text {abcde }}$ & 0 & 17 & $20.1053^{\text {defg }}$ & 0 \\
\hline 3 & $18.2134^{\mathrm{ab}}$ & 0 & 18 & $19.2003^{\text {abcde }}$ & 0 \\
\hline 4 & $23.4517^{\mathrm{jk}}$ & 0 & 19 & $20.1241^{\text {defg }}$ & 0 \\
\hline 5 & $18.7562^{\mathrm{abc}}$ & 0 & 20 & $20.3156^{\text {defgh }}$ & 0 \\
\hline 6 & $19.3162^{\text {abcde }}$ & 0 & 21 & $19.5420^{\text {cdef }}$ & 0 \\
\hline 7 & $23.4510^{\mathrm{jk}}$ & 0 & 22 & $24.5102^{k}$ & 0 \\
\hline 8 & $22.4610^{\mathrm{ij}}$ & 0 & 23 & $19.0040^{\mathrm{abcd}}$ & 0 \\
\hline 9 & $21.4531^{\mathrm{hi}}$ & 0 & 24 & $18.2013^{\mathrm{ab}}$ & 0 \\
\hline 10 & $21.2549^{\mathrm{gh}}$ & 0 & 25 & $20.1600^{\operatorname{defg}}$ & 0 \\
\hline 11 & $21.0207^{\mathrm{gh}}$ & 0 & 26 & $24.4516^{\mathrm{k}}$ & 0 \\
\hline 12 & $20.4021^{\mathrm{efgh}}$ & 0 & 27 & $20.1463^{\operatorname{defg}}$ & 0 \\
\hline 13 & $20.7210^{\mathrm{fgh}}$ & 0 & & & \\
\hline
\end{tabular}

The pickle liquids are liquid part of the pickle, were analyzed for the anti-microbial property. All the formulations showed anti-microbial activity against tested microbes. The formulas 1, 2, and 3 showed higher antimicrobial activity than that of the other pickles, especially against $S$. aureus, and $B$. cereus (Table 9). It is known that the LAB in fermented foods, such as kimchi, fermented cabbage, and yogurt, are active against contaminating microbial population (Lee et al., 2009; Mitra et al., 2010; Patel et al., 2014). Antimicrobial nature of LAB5 (starter culture) (Table 2), and the presence of garlic, and ginger in the pickle mix enhanced the antimicrobial activity of the pickle formulation (Table 9).

Naturally fermented foods and beverages contain beneficial, non-beneficial, and pathogenic microbes (Tamang et al., 2016). The ratio of the microbial load determines the quality of the product and functional property of the food in association with active compounds of raw materials used for the preparation. Several functional properties of the microbes in fermented foods were reported such as probiotics, antimicrobial, antioxidant, peptide production, fibrinolytic activity, etc (de Mejia et al., 2010; Meira et al., 2012; Perna et al., 2013; Hill et al., 2014). Some of the LAB isolated from fermented foods are used for the production of fermented mushroom beverages with a high content of L-glutamine, L-glutamic acid, and $\gamma$-aminobutyric acid (Woraharn et al., 2015; Woraharn et al., 2016). The lactobacillus fermented plant juice can be used as an active ingredient for mouthwash formulas (Sirilun et al., 2016). 
Table 8: The amount of ethanol in pickle formulations at different time points. a-n indicates the significant difference among the samples $(\mathrm{p}<0.05)$.

\begin{tabular}{|c|c|c|c|c|c|c|c|c|c|}
\hline \multirow{2}{*}{ Formula No. } & \multicolumn{4}{|c|}{ Ethanol $(\%, v / v)$} & \multirow{2}{*}{ Formula No. } & \multicolumn{4}{|c|}{ Ethanol $(\%, v / v)$} \\
\hline & Day 0 & Day 7 & Day 15 & Day 30 & & Day 0 & Day 7 & Day 15 & Day 30 \\
\hline Control-1 & $0.152^{\mathrm{a}}$ & $0.184^{\mathrm{a}}$ & $0.201^{\mathrm{a}}$ & $0.251^{\mathrm{a}}$ & 14 & $0.312^{\mathrm{de}}$ & $0.420^{\mathrm{g}}$ & $0.513^{\mathrm{h}}$ & $0.630^{\mathrm{g}}$ \\
\hline Control-2 & $0.301^{\mathrm{d}}$ & $0.370^{\text {cd }}$ & $0.402^{\mathrm{c}}$ & $0.493^{b}$ & 15 & $0.240^{\mathrm{c}}$ & $0.403^{\mathrm{efg}}$ & $0.610^{\mathrm{jk}}$ & $0.795^{\mathrm{ki}}$ \\
\hline 1 & $0.295^{\mathrm{d}}$ & $0.416^{\mathrm{g}}$ & $0.512^{\mathrm{h}}$ & $0.670^{\mathrm{ij}}$ & 16 & $0.292^{\mathrm{d}}$ & $0.401^{\text {efg }}$ & $0.452^{\mathrm{e}}$ & $0.610^{\text {def }}$ \\
\hline 2 & $0.289^{\mathrm{d}}$ & $0.354^{\mathrm{c}}$ & $0.377^{\mathrm{b}}$ & $0.482^{\mathrm{b}}$ & 17 & $0.301^{\mathrm{d}}$ & $0.361^{\mathrm{c}}$ & $0.420^{\mathrm{d}}$ & $0.552^{\mathrm{c}}$ \\
\hline 3 & $0.310^{\mathrm{d}}$ & $0.348^{\mathrm{bc}}$ & $0.490^{\mathrm{fg}}$ & $0.620^{\mathrm{fg}}$ & 18 & $0.374^{\text {gh }}$ & $0.392^{\text {ef }}$ & $0.425^{\mathrm{d}}$ & $0.601^{\mathrm{d}}$ \\
\hline 4 & $0.301^{\mathrm{d}}$ & $0.385^{\text {de }}$ & $0.503^{\mathrm{gh}}$ & $0.831^{\mathrm{n}}$ & 19 & $0.295^{\mathrm{d}}$ & $0.420^{\mathrm{g}}$ & $0.510^{\mathrm{h}}$ & $0.613^{\mathrm{def}}$ \\
\hline 5 & $0.351^{\text {fgh }}$ & $0.400^{\mathrm{efg}}$ & $0.531^{\mathrm{i}}$ & $0.790^{k}$ & 20 & $0.321^{\text {def }}$ & $0.421^{\mathrm{g}}$ & $0.621^{\mathrm{k}}$ & $0.870^{\circ}$ \\
\hline 6 & $0.298^{\mathrm{d}}$ & $0.410^{\mathrm{fg}}$ & $0.602^{\mathrm{j}}$ & $0.830^{\mathrm{n}}$ & 21 & $0.321^{\text {def }}$ & $0.420^{\mathrm{g}}$ & $0.510^{\mathrm{h}}$ & $0.649^{\mathrm{h}}$ \\
\hline 7 & $0.381^{\mathrm{h}}$ & $0.469^{\mathrm{hi}}$ & $0.608^{\mathrm{jk}}$ & $0.819^{\mathrm{mn}}$ & 22 & $0.310^{\mathrm{d}}$ & $0.390^{\text {def }}$ & $0.420^{\mathrm{d}}$ & $0.600^{\mathrm{d}}$ \\
\hline 8 & $0.320^{\text {def }}$ & $0.400^{\text {efg }}$ & $0.621^{\mathrm{k}}$ & $0.795^{\mathrm{k}}$ & 23 & $0.204^{\mathrm{b}}$ & $0.351^{\mathrm{bc}}$ & $0.642^{1}$ & $0.812^{\mathrm{lm}}$ \\
\hline 9 & $0.310^{\mathrm{d}}$ & $0.408^{\text {efg }}$ & $0.510^{\mathrm{h}}$ & $0.645^{\mathrm{h}}$ & 24 & $0.315^{\mathrm{de}}$ & $0.390^{\text {def }}$ & $0.420^{\mathrm{d}}$ & $0.605^{\text {de }}$ \\
\hline 10 & $0.351^{\mathrm{fgh}}$ & $0.490^{\mathrm{j}}$ & $0.689^{\mathrm{m}}$ & $0.800^{\mathrm{kl}}$ & 25 & $0.294^{\mathrm{d}}$ & $0.356^{\mathrm{c}}$ & $0.482^{\mathrm{f}}$ & $0.610^{\text {def }}$ \\
\hline 11 & $0.351^{\mathrm{fgh}}$ & $0.391^{\mathrm{def}}$ & $0.541^{\mathrm{i}}$ & $0.618^{\mathrm{efg}}$ & 26 & $0.298^{\mathrm{d}}$ & $0.333^{\mathrm{b}}$ & $0.512^{\mathrm{h}}$ & $0.683^{\mathrm{j}}$ \\
\hline 12 & $0.345^{\text {efg }}$ & $0.480^{\mathrm{ij}}$ & $0.681^{\mathrm{m}}$ & $0.824^{\mathrm{mn}}$ & 27 & $0.301^{\mathrm{d}}$ & $0.359^{\mathrm{c}}$ & $0.422^{\mathrm{h}}$ & $0.492^{\mathrm{b}}$ \\
\hline 13 & $0.320^{\text {def }}$ & $0.450^{\mathrm{h}}$ & $0.510^{\mathrm{h}}$ & $0.658^{\mathrm{hi}}$ & & & & & \\
\hline
\end{tabular}

Table 9: Anti-microbial property of pickle formulations against representative food pathogens.

\begin{tabular}{|c|c|c|c|c|c|}
\hline \multirow{3}{*}{ Formula No. } & \multicolumn{5}{|c|}{ Mean value of zone of inhibition (mm) } \\
\hline & E. coli & S. aureus & B. cereus & P. aeruginosa & C. albicans \\
\hline & ATCC 25922 & ATCC 25923 & & ATCC 27853 & ATCC 90028 \\
\hline Control-1 & + & + & + & + & - \\
\hline Control-2 & ++ & ++ & ++ & ++ & + \\
\hline 1 & +++ & +++ & +++ & ++ & ++ \\
\hline 2 & +++ & +++ & +++ & ++ & ++ \\
\hline 3 & +++ & +++ & +++ & ++ & ++ \\
\hline 4 & ++ & + & ++ & + & + \\
\hline 5 & ++ & + & ++ & + & + \\
\hline 6 & ++ & + & ++ & + & + \\
\hline 7 & ++ & + & +++ & ++ & + \\
\hline 8 & ++ & + & +++ & ++ & + \\
\hline 9 & ++ & + & +++ & ++ & + \\
\hline 10 & + & + & + & + & + \\
\hline 11 & + & + & + & + & + \\
\hline 12 & + & + & + & + & + \\
\hline 13 & ++ & + & ++ & + & + \\
\hline 14 & ++ & + & ++ & + & + \\
\hline 15 & ++ & + & ++ & + & + \\
\hline 16 & ++ & + & +++ & ++ & + \\
\hline 17 & ++ & + & +++ & ++ & + \\
\hline 18 & ++ & + & +++ & ++ & + \\
\hline 19 & ++ & ++ & + & + & ++ \\
\hline 20 & ++ & ++ & + & + & ++ \\
\hline 21 & ++ & ++ & + & + & ++ \\
\hline 22 & ++ & ++ & ++ & + & ++ \\
\hline 23 & ++ & ++ & ++ & + & ++ \\
\hline 24 & ++ & ++ & ++ & + & ++ \\
\hline 25 & +++ & ++ & +++ & ++ & ++ \\
\hline
\end{tabular}


26

27

Note: + denotes inhibition zone of $<10 \mathrm{~mm} ;++$ denotes inhibition zone of $11-19 \mathrm{~mm} ;+++$ denotes inhibition zone of $\geq 20 \mathrm{~mm}$.

Table 10: Cholesterol content $(\mu \mathrm{g})$ in the medium. a-n indicates the significant difference among the samples $(\mathrm{p}<0.05)$.

\begin{tabular}{|c|c|c|c|c|c|c|c|c|}
\hline Formula No. & Day 1 & Day 2 & Day 3 & Day 5 & Day 10 & Day 15 & Day 20 & Day 30 \\
\hline Control-1 & $76.21^{\mathrm{h}}$ & $74.00^{\mathrm{k}}$ & $69.00^{\circ}$ & $64.50^{\mathrm{p}}$ & $62.00^{\mathrm{n}}$ & $60.50^{\mathrm{n}}$ & $60.00^{\mathrm{n}}$ & $59.96^{\circ}$ \\
\hline Control-2 & $74.00^{\mathrm{de}}$ & $65.00^{\mathrm{d}}$ & $49.80^{d}$ & $41.00^{\mathrm{c}}$ & $39.00^{\mathrm{d}}$ & $39.00^{\mathrm{d}}$ & $38.00^{\mathrm{b}}$ & $37.11^{\mathrm{c}}$ \\
\hline 1 & $73.50^{\mathrm{cd}}$ & $63.00^{\mathrm{c}}$ & $43.00^{\mathrm{b}}$ & $37.50^{\mathrm{b}}$ & $36.00^{\mathrm{c}}$ & $33.00^{\mathrm{b}}$ & $34.00^{\mathrm{a}}$ & $35.11^{\mathrm{b}}$ \\
\hline 2 & $73.00^{\mathrm{bc}}$ & $62.00^{\mathrm{b}}$ & $42.00^{\mathrm{a}}$ & $37.00^{\mathrm{b}}$ & $33.00^{\mathrm{a}}$ & $35.00^{c}$ & $34.00^{\mathrm{a}}$ & $34.00^{\mathrm{a}}$ \\
\hline 3 & $72.50^{\mathrm{ab}}$ & $61.00^{\mathrm{a}}$ & $44.00^{\mathrm{c}}$ & $36.00^{\mathrm{a}}$ & $35.00^{\mathrm{b}}$ & $32.00^{\mathrm{a}}$ & $34.00^{\mathrm{a}}$ & $33.80^{\mathrm{a}}$ \\
\hline 4 & $77.00^{\mathrm{i}}$ & $65.50^{\mathrm{d}}$ & $52.50^{\mathrm{e}}$ & $46.50^{\text {ef }}$ & $42.50^{\text {ef }}$ & $43.00^{\mathrm{f}}$ & $41.00^{\mathrm{c}}$ & $43.50^{\mathrm{fg}}$ \\
\hline 5 & $77.00^{\mathrm{i}}$ & $65.00^{\mathrm{d}}$ & $53.00^{\mathrm{e}}$ & $47.00^{\mathrm{f}}$ & $42.50^{\mathrm{f}}$ & $43.00^{\mathrm{f}}$ & $45.00^{\mathrm{f}}$ & $43.09^{\mathrm{f}}$ \\
\hline 6 & $77.00^{\mathrm{i}}$ & $66.00^{\mathrm{d}}$ & $55.00^{\mathrm{f}}$ & $46.00^{\mathrm{e}}$ & $44.80^{\mathrm{h}}$ & $44.80^{\mathrm{g}}$ & $44.00^{\mathrm{e}}$ & $44.23^{\mathrm{gi}}$ \\
\hline 7 & $76.50^{\mathrm{hi}}$ & $69.95^{\mathrm{gh}}$ & $59.90^{\mathrm{hi}}$ & $57.00^{\mathrm{h}}$ & $55.00^{j}$ & $55.00^{\mathrm{i}}$ & $54.00^{\mathrm{i}}$ & $48.23^{\mathrm{h}}$ \\
\hline 8 & $76.50^{\mathrm{hi}}$ & $70.15^{\mathrm{gh}}$ & $60.50^{\mathrm{ij}}$ & $58.00^{\mathrm{ij}}$ & $55.00^{j}$ & $55.00^{\mathrm{i}}$ & $55.00^{\mathrm{jk}}$ & $46.29^{\mathrm{h}}$ \\
\hline 9 & $76.50^{\mathrm{hi}}$ & $69.95^{\text {gh }}$ & $60.50^{\mathrm{ij}}$ & $55.00^{\mathrm{g}}$ & $55.00^{\mathrm{j}}$ & $55.00^{\mathrm{i}}$ & $55.00^{\mathrm{jk}}$ & $46.29^{\mathrm{e}}$ \\
\hline 10 & $76.50^{\text {hi }}$ & $67.50^{\mathrm{e}}$ & $64.00^{1}$ & $46.00^{\mathrm{e}}$ & $41.50^{\mathrm{e}}$ & $41.50^{\mathrm{e}}$ & $40.50^{c}$ & $41.13^{\mathrm{d}}$ \\
\hline 11 & $76.50^{\mathrm{hi}}$ & $67.50^{\mathrm{e}}$ & $65.00^{\mathrm{m}}$ & $46.00^{\mathrm{e}}$ & $43.50^{\mathrm{g}}$ & $41.50^{\mathrm{e}}$ & $40.50^{c}$ & $39.89^{d}$ \\
\hline 12 & $76.50^{\mathrm{hi}}$ & $69.50^{\mathrm{fg}}$ & $66.00^{\mathrm{n}}$ & $44.50^{\mathrm{d}}$ & $43.50^{\mathrm{g}}$ & $41.50^{\mathrm{e}}$ & $43.00^{\mathrm{d}}$ & $39.89^{j}$ \\
\hline 13 & $72.25^{\mathrm{a}}$ & $65.50^{\mathrm{d}}$ & $59.50^{\mathrm{gh}}$ & $57.75^{\mathrm{i}}$ & $54.00^{\mathrm{i}}$ & $54.00^{\mathrm{h}}$ & $55.50^{\mathrm{k}}$ & $51.29^{\mathrm{j}}$ \\
\hline 14 & $72.25^{\mathrm{ac}}$ & $65.50^{\mathrm{d}}$ & $59.50^{\mathrm{gh}}$ & $55.50^{\mathrm{g}}$ & $55.00^{\mathrm{j}}$ & $54.00^{\mathrm{h}}$ & $52.75^{\mathrm{h}}$ & $50.87^{\mathrm{j}}$ \\
\hline 15 & $76.80^{\mathrm{hi}}$ & $67.75^{\mathrm{e}}$ & $59.50^{\mathrm{g}}$ & $55.50^{\mathrm{g}}$ & $55.00^{j}$ & $54.00^{\mathrm{h}}$ & $52.75^{\mathrm{h}}$ & $50.87^{\mathrm{k}}$ \\
\hline 16 & $75.00^{\mathrm{fg}}$ & $71.00^{\mathrm{i}}$ & $62.50^{\mathrm{k}}$ & $59.00^{\mathrm{kl}}$ & $56.50^{\mathrm{k}}$ & $55.00^{\mathrm{i}}$ & $54.00^{\mathrm{i}}$ & $53.14^{\mathrm{k}}$ \\
\hline 17 & $75.00^{\mathrm{fg}}$ & $71.00^{\mathrm{i}}$ & $62.50^{\mathrm{k}}$ & $59.00^{k 1}$ & $56.50^{\mathrm{k}}$ & $55.00^{\mathrm{i}}$ & $54.00^{\mathrm{i}}$ & $53.14^{1}$ \\
\hline 18 & $74.50^{\text {ef }}$ & $71.00^{\mathrm{i}}$ & $62.50^{\mathrm{k}}$ & $59.00^{\mathrm{k} 1}$ & $56.50^{\mathrm{k}}$ & $55.00^{\mathrm{i}}$ & $54.00^{\mathrm{i}}$ & $54.40^{\mathrm{kl}}$ \\
\hline 19 & $77.00^{\mathrm{i}}$ & $73.00^{j}$ & $60.00 \mathrm{~h}^{\mathrm{i}}$ & $58.50^{\mathrm{jk}}$ & $56.00^{\mathrm{k}}$ & $56.00^{j}$ & $56.50^{1}$ & $54.64^{\mathrm{n}}$ \\
\hline 20 & $78.00^{j}$ & $73.00^{j}$ & $61.00^{j}$ & $59.50^{\mathrm{lm}}$ & $59.50^{\mathrm{m}}$ & $59.50^{\mathrm{lm}}$ & $59.50^{\mathrm{mn}}$ & $57.28^{\mathrm{n}}$ \\
\hline 21 & $75.50^{\mathrm{g}}$ & $73.00^{j}$ & $61.00^{\mathrm{j}}$ & $58.50^{\mathrm{jk}}$ & $59.00^{\mathrm{m}}$ & $59.50^{\mathrm{lm}}$ & $59.50^{\mathrm{mn}}$ & $57.28^{n}$ \\
\hline 22 & $73.50^{\mathrm{cd}}$ & $67.50^{\mathrm{e}}$ & $64.50^{\mathrm{lm}}$ & $59.00^{\mathrm{kl}}$ & $57.50^{1}$ & $57.50^{\mathrm{k}}$ & $57.00^{1}$ & $56.87^{\mathrm{mn}}$ \\
\hline 23 & $73.50^{\mathrm{cd}}$ & $69.00^{\mathrm{f}}$ & $64.50^{\mathrm{lm}}$ & $59.00^{\mathrm{kl}}$ & $57.50^{1}$ & $57.50^{\mathrm{k}}$ & $59.00^{\mathrm{m}}$ & $56.87^{\mathrm{mn}}$ \\
\hline 24 & $73.50^{\mathrm{cd}}$ & $69.00^{\mathrm{f}}$ & $62.00^{\mathrm{k}}$ & $60.50^{\text {no }}$ & $59.50^{\mathrm{m}}$ & $59.75^{\mathrm{m}}$ & $59.00^{\mathrm{m}}$ & $57.38^{\mathrm{n}}$ \\
\hline 25 & $75.50^{\mathrm{fg}}$ & $70.50^{\mathrm{hi}}$ & $64.00^{1}$ & $61.00^{\circ}$ & $57.50^{1}$ & $54.00^{\mathrm{h}}$ & $52.00^{\mathrm{g}}$ & $56.23^{\mathrm{m}}$ \\
\hline 26 & $77.00^{\mathrm{i}}$ & $68.00^{\mathrm{e}}$ & $64.00^{1}$ & $61.00^{\circ}$ & $55.00^{\mathrm{j}}$ & $59.00^{1}$ & $54.50^{\mathrm{ij}}$ & $54.30^{1}$ \\
\hline 27 & $77.00^{\mathrm{i}}$ & $68.00^{\mathrm{e}}$ & $64.00^{1}$ & $60.00^{\mathrm{mn}}$ & $57.50^{1}$ & $54.50^{\mathrm{hi}}$ & $54.50^{\mathrm{ij}}$ & $54.30^{1}$ \\
\hline
\end{tabular}

The LAB isolate used in the study has lipid utilizing property and BSH activity. Thus, the cholesterol content in the pickle liquids and LAB cells were kinetically (at day 1, 2, $3,5,10,15,20$ and 30) measured to reveal the cholesterol exploiting nature of selected LAB strain. The concentration of the cholesterol in pickle liquid was gradually reduced in all tested pickle formulas, and significant changes were observed after 30 days of pickling compared to the cholesterol content on the first day of respective pickle samples. Formulas no. 1, 2, and 3 showed a more effective reduction in cholesterol content in the respective pickle liquids (from $73.50,73$, and 72.50 to $35.11,34$, and 33.80 $\mu \mathrm{g}$, respectively) (Table 10). The cholesterol content inside the LAB cells was increased significantly compared to day 1 in all the formulas. The formula no. 1, 2, and 3 showed a more significant increase in cholesterol content in LAB cells (from 6, 6 and 6 to $24.15,24.40$, and $24.68 \mu \mathrm{g}$, respectively) (Table 11). The results suggested that the LAB strain potentially intakes the cholesterol present in the pickles, which can be used by the organism as a source of energy.

The selected LAB isolate (LAB5) has been predicted as L. plantarum based on the biochemical profile (Table 3 ) and a previous report (Todorov and Franco, 2010). A study revealed the significant level of reduction in total cholesterol (13.6\%) levels after 12 weeks of consumption of Lactobacillus plantarum cocktail (a mixture of three strains) compared with placebo (Natural news, 2012). Choi et al. (2013) reported that the consumption of kimchi reduced the total cholesterol and low-density lipoprotein-C level among the young healthy volunteers. 
Table 11: Cholesterol content in LAB cells. a-k indicates the significant difference among the samples $(\mathrm{p}<0.05)$.

\begin{tabular}{|c|c|c|c|c|c|c|c|c|}
\hline Formula No. & Day 1 & Day 2 & Day 3 & Day 5 & Day 10 & Day 15 & Day 20 & Day 30 \\
\hline Control-1 & $2.00^{\mathrm{a}}$ & $2.80^{\mathrm{a}}$ & $4.00^{\mathrm{a}}$ & $7.25^{\mathrm{a}}$ & $7.80^{\mathrm{a}}$ & $8.00^{\mathrm{a}}$ & $7.80^{\mathrm{a}}$ & $7.45^{\mathrm{a}}$ \\
\hline Control-2 & $5.00^{\mathrm{f}}$ & $7.30^{\mathrm{gh}}$ & $13.50^{\mathrm{j}}$ & $18.00^{\mathrm{h}}$ & $19.00^{\mathrm{i}}$ & $22.50^{\mathrm{h}}$ & $22.75^{\mathrm{j}}$ & $21.67^{j}$ \\
\hline 1 & $6.00^{\mathrm{g}}$ & $8.50^{\mathrm{k}}$ & $14.90^{\mathrm{k}}$ & $18.50^{\mathrm{h}}$ & $22.00^{\mathrm{j}}$ & $23.00^{\mathrm{hi}}$ & $22.75^{j}$ & $24.15^{\mathrm{k}}$ \\
\hline 2 & $6.00^{\mathrm{g}}$ & $8.50^{\mathrm{k}}$ & $14.90^{\mathrm{k}}$ & $20.00^{\mathrm{i}}$ & $23.50^{\mathrm{k}}$ & $23.50^{\mathrm{i}}$ & $22.75^{j}$ & $24.40^{\mathrm{k}}$ \\
\hline 3 & $6.00^{\mathrm{g}}$ & $8.50^{\mathrm{k}}$ & $14.00^{\mathrm{j}}$ & $18.50^{\mathrm{h}}$ & $23.00^{\mathrm{k}}$ & $23.00^{\mathrm{hi}}$ & $22.75^{j}$ & $24.68^{j}$ \\
\hline 4 & $4.00^{\mathrm{e}}$ & $7.50^{\text {ghi }}$ & $12.50^{\mathrm{i}}$ & $14.50^{\mathrm{f}}$ & $15.70^{\mathrm{f}}$ & $17.50^{\mathrm{e}}$ & $17.50^{\mathrm{fg}}$ & $18.65^{\mathrm{i}}$ \\
\hline 5 & $4.30^{\mathrm{e}}$ & $8.00^{\mathrm{ijk}}$ & $13.50^{\mathrm{j}}$ & $13.00^{\mathrm{cd}}$ & $17.00^{\mathrm{g}}$ & $17.50^{\mathrm{e}}$ & $17.50^{\mathrm{fg}}$ & $18.65^{\mathrm{j}}$ \\
\hline 6 & $5.00 \mathrm{f}$ & $7.00^{\mathrm{fg}}$ & $11.50^{\mathrm{gh}}$ & $14.50^{\mathrm{f}}$ & $16.00^{\mathrm{f}}$ & $17.50^{\mathrm{e}}$ & $17.50^{\mathrm{fg}}$ & $18.22^{\mathrm{gh}}$ \\
\hline 7 & $4.25 \mathrm{e}$ & $4.40^{\mathrm{c}}$ & $10.50^{\mathrm{f}}$ & $13.50^{\mathrm{de}}$ & $16.00^{\mathrm{f}}$ & $18.50^{\mathrm{f}}$ & $17.50^{\mathrm{fg}}$ & $16.43^{\mathrm{f}}$ \\
\hline 8 & $4.25^{\mathrm{e}}$ & $6.00^{\mathrm{de}}$ & $11.50^{\mathrm{gh}}$ & $12.50^{\mathrm{c}}$ & $16.00^{\mathrm{f}}$ & $17.50^{\mathrm{e}}$ & $17.50^{\mathrm{fg}}$ & $16.43^{\mathrm{gh}}$ \\
\hline 9 & $4.25^{\mathrm{e}}$ & $4.25^{\mathrm{bc}}$ & $10.50^{\mathrm{f}}$ & $12.50^{\mathrm{c}}$ & $16.00^{\mathrm{f}}$ & $17.50^{\mathrm{e}}$ & $16.80^{\text {ef }}$ & $17.37^{\mathrm{f}}$ \\
\hline 10 & $4.25^{\mathrm{e}}$ & $7.00^{\mathrm{fg}}$ & $13.75^{\mathrm{j}}$ & $15.50^{\mathrm{g}}$ & $16.80^{\mathrm{g}}$ & $17.80^{\mathrm{e}}$ & $16.80^{\text {ef }}$ & $17.31^{\mathrm{j}}$ \\
\hline 11 & $4.25^{\mathrm{e}}$ & $8.25^{\mathrm{jk}}$ & $13.75^{\mathrm{j}}$ & $16.00^{\mathrm{g}}$ & $18.00^{\mathrm{h}}$ & $17.90^{\mathrm{e}}$ & $18.50^{\mathrm{hi}}$ & $18.32^{\mathrm{j}}$ \\
\hline 12 & $4.25^{\mathrm{e}}$ & $7.70^{\text {hij }}$ & $12.50^{\mathrm{i}}$ & $15.50^{\mathrm{g}}$ & $16.80^{\mathrm{g}}$ & $17.75^{\mathrm{e}}$ & $17.80^{\mathrm{gh}}$ & $17.31^{\mathrm{i}}$ \\
\hline 13 & $4.50 \mathrm{e}$ & $6.50^{\mathrm{ef}}$ & $12.00^{\mathrm{hi}}$ & $16.00^{\mathrm{g}}$ & $15.00^{\mathrm{e}}$ & $17.50^{\mathrm{e}}$ & $17.00^{\mathrm{efg}}$ & $16.96^{\mathrm{hi}}$ \\
\hline 14 & $4.00^{\mathrm{e}}$ & $6.50^{\mathrm{ef}}$ & $12.00^{\mathrm{hi}}$ & $16.00^{\mathrm{g}}$ & $15.00^{\mathrm{e}}$ & $17.50^{\mathrm{e}}$ & $17.00^{\mathrm{efg}}$ & $17.36^{\mathrm{hi}}$ \\
\hline 15 & $4.50^{\mathrm{e}}$ & $7.00^{\mathrm{fg}}$ & $12.00^{\mathrm{hi}}$ & $16.00^{\mathrm{g}}$ & $15.00^{\mathrm{e}}$ & $17.50^{\mathrm{e}}$ & $17.00^{\mathrm{efg}}$ & $17.00^{\mathrm{hi}}$ \\
\hline 16 & $3.50^{\mathrm{d}}$ & $4.35^{\mathrm{bc}}$ & $9.00^{\mathrm{de}}$ & $12.50^{\mathrm{c}}$ & $12.50^{\mathrm{b}}$ & $13.50^{\mathrm{b}}$ & $12.75^{\mathrm{b}}$ & $13.66^{\mathrm{de}}$ \\
\hline 17 & $3.00^{\mathrm{c}}$ & $4.00^{\mathrm{bc}}$ & $8.50^{\mathrm{cd}}$ & $13.75^{\mathrm{e}}$ & $13.75^{\mathrm{c}}$ & $13.00^{\mathrm{b}}$ & $12.75^{\mathrm{b}}$ & $12.75^{\mathrm{cd}}$ \\
\hline 18 & $3.50^{\mathrm{d}}$ & $4.25^{\mathrm{bc}}$ & $8.50^{\mathrm{cd}}$ & $13.75^{\mathrm{e}}$ & $14.00^{\mathrm{cd}}$ & $13.50^{\mathrm{b}}$ & $13.50^{\mathrm{c}}$ & $13.66^{\mathrm{cd}}$ \\
\hline 19 & $4.25^{\mathrm{e}}$ & $7.75^{\mathrm{hij}}$ & $11.00^{\mathrm{fg}}$ & $13.00^{\mathrm{cd}}$ & $17.00^{\mathrm{g}}$ & $17.50^{\mathrm{e}}$ & $17.80^{\mathrm{gh}}$ & $16.43^{\mathrm{fg}}$ \\
\hline 20 & $4.25^{\mathrm{e}}$ & $7.75^{\text {hij }}$ & $12.00^{\mathrm{hi}}$ & $13.00^{\mathrm{cd}}$ & $17.00^{\mathrm{g}}$ & $17.50^{\mathrm{e}}$ & $17.80^{\mathrm{gh}}$ & $16.79^{\mathrm{hi}}$ \\
\hline 21 & $4.25^{\mathrm{e}}$ & $7.75^{\text {hij }}$ & $9.50^{\mathrm{e}}$ & $13.00^{\mathrm{cd}}$ & $17.00^{\mathrm{g}}$ & $16.50^{\mathrm{d}}$ & $17.80^{\mathrm{gh}}$ & $16.60^{\mathrm{e}}$ \\
\hline 22 & $3.50^{\mathrm{d}}$ & $5.50^{\mathrm{d}}$ & $8.50^{\mathrm{cd}}$ & $13.50^{\text {de }}$ & $18.25^{\mathrm{h}}$ & $19.50^{\mathrm{g}}$ & $19.00^{\mathrm{i}}$ & $19.46^{\mathrm{cd}}$ \\
\hline 23 & $3.50^{\mathrm{d}}$ & $4.50^{\mathrm{c}}$ & $8.50^{\mathrm{cd}}$ & $14.00^{\text {ef }}$ & $18.25^{\mathrm{h}}$ & $19.50^{\mathrm{g}}$ & $19.00^{\mathrm{i}}$ & $19.00^{\mathrm{cd}}$ \\
\hline 24 & $3.50^{\mathrm{d}}$ & $5.50^{\mathrm{d}}$ & $8.00^{\mathrm{c}}$ & $14.50^{\mathrm{f}}$ & $18.25^{\mathrm{h}}$ & $19.50^{\mathrm{g}}$ & $19.00^{\mathrm{i}}$ & $18.68^{\mathrm{c}}$ \\
\hline 25 & $2.50^{\mathrm{b}}$ & $3.75^{\mathrm{b}}$ & $6.50^{\mathrm{b}}$ & $11.50^{\mathrm{b}}$ & $14.50^{\text {de }}$ & $16.00^{\mathrm{cd}}$ & $15.50^{\mathrm{d}}$ & $16.57^{b}$ \\
\hline 26 & $2.50^{\mathrm{b}}$ & $3.75^{\mathrm{b}}$ & $7.00^{\mathrm{b}}$ & $11.50^{\mathrm{b}}$ & $14.50^{\text {de }}$ & $15.50^{\mathrm{c}}$ & $16.50^{\mathrm{e}}$ & $16.57^{\mathrm{b}}$ \\
\hline 27 & $2.50^{\mathrm{b}}$ & $3.00^{\mathrm{a}}$ & $6.50^{\mathrm{b}}$ & $11.50^{\mathrm{b}}$ & $14.00^{\mathrm{cd}}$ & $15.50^{\mathrm{c}}$ & $14.00^{\mathrm{c}}$ & $15.78^{\mathrm{b}}$ \\
\hline
\end{tabular}
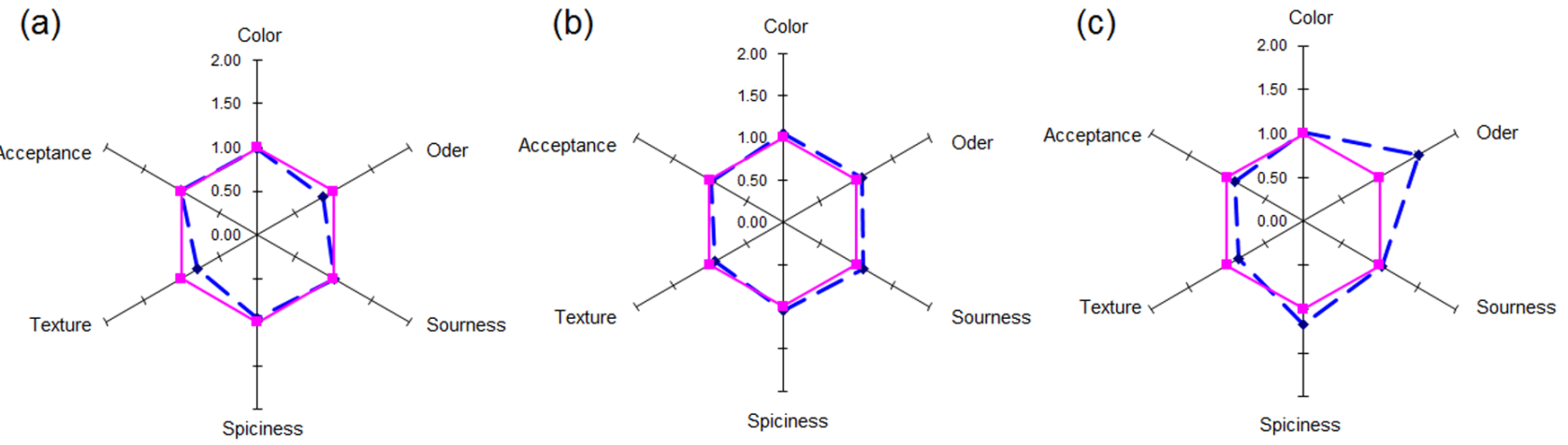

- Sample score

- Ideal score

Fig. 1: Representation of sensory evaluation of pickle formulas 1 (a), 2 (b), and 3 (c) after two months of storage at room temperature. The pickle formula 2 displayed the score parallel to the ideal score, than other formulas.

The customer' acceptance and the stability of a product are more important to succeed the marketing of any product. The food products are subjected to the sensory evaluation and acceptance rate of the product, before marketing or mass production. All the formulated pickles were subjected to sensory evaluation by twenty independent, healthy human volunteers. The opinion about color, taste, odor and general acceptance of the pickles were collected, and the product score was plotted with the 
ideal score. The results suggested that the pickle formulas 1, 2, and 3 are the most acceptable pickle formulations by the volunteers (Data not shown).

A successful probiotic pickle product should maintain an effective dose $\left(>10^{6} \mathrm{CFU} / \mathrm{ml}\right)$ of probiotic until the proposed shelf life of the product, usually two or more months (Sanders et al., 2010). Hence, the selected pickle formulas were stored at room temperature for 60 days to assess the stability of probiotic strain in the pickles, and shelf life of the pickles. The amount of LAB in the pickles was gradually reduced over the period of storage, and the level of reduction also varied among the pickles. The pickle formula 1 retains the relatively high LAB cells during storage followed by formulas 2 , and 3 (Table 11). The sensory evaluation data showed that all three pickles were accepted by the volunteers after the storage period. More specifically, pickle formula 2 was selected as the best pickle formula in the study by healthy volunteers (Fig. 1).

\section{CONCLUSION}

The present study reported the successful isolation of probiotic LAB with cholesterol utilizing property from fermented foods of Northern Thailand. The MG based pickle was formulated with a different concentration of seasonings and LAB starter culture. The formulated pickles have been evaluated for the organic acids, alcohol content, and cholesterol-lowering property. The sensory evaluation and stability studies also proved that the formulated pickle was good for the human consumption. Further, the randomized clinical trial is required to explore the in vivo cholesterol lowering the ability of the formulated pickle. LAB5 mediated fermented MG pickle may be considered as the functional food to control the cholesterol.

\section{ACKNOWLEDGMENTS}

Authors gratefully acknowledge the Chiang Mai University grant (CMU-grant) for the support, and the Faculty of Pharmacy and Chiang Mai University, Chiang Mai, Thailand for the necessary support. BSS wish to acknowledge the CMU Post-Doctoral Fellowship, Chiang Mai University, Chiang Mai, Thailand.

\section{CONFLICT OF INTEREST}

All authors declare that they have no conflict of interest.

\section{REFERENCES}

Cappuccino JG, Sherman N. Microbiology: a laboratory manual. 9th Ed. San Francisco: Benjamin-Cummings; 2011.

Chaiyasut C, Makhamrueang N, Peerajan S, Sivamaruthi BS. Assessment of organic acid content, and brix value of representative indigenous fermented plant beverages of Thailand. Asian J Pharm Clin Res. 2017a; 10(1):350-354.

Chaiyasut C, Sivamaruthi BS, Peerajan S, Sirilun S, Chaiyasut K, Kesika P. Assessment of heavy metals, minerals, alcohol, and fusel oil content of selected fermented plant beverages of Thailand. Int Food Res J. 2017b; 24(1):126-133.

Chang JY, Lee HJ, Chang HC. Identification of the agent from Lactobacillus plantarum KFRI464 that enhances bacteriocin production by Leuconostoc citreum GJ7. J Appl Microbiol. 2007; 103(6):2504-2515.

Chen CC, Chyau CC, Liao CC, Hu TJ, Kuo CF. Enhanced antiinflammatory activities of Monascus pilosus fermented products by addition of ginger to the medium. J Agric Food Chem. 2010; 58(22):12006-12013.
Cheng SJ, Sala M, Li MH, Courtois I, Chouroulinkov I. Promoting effect of Roussin's red identified in pickled vegetables from Linxian China. Carcinogenesis. 1981; 2(4):313-319.

Cheng SJ, Sala M, Li MH, Wang MY, Pot-Deprun J, Chouroulinkov I. Mutagenic, transforming and promoting effect of pickled vegetables from Linxian County, China. Carcinogenesis. 1980; 1(8):685692.

Choi IH, Noh JS, Han J-S, Kim HJ, Han E-S, Song YO. Kimchi, a fermented vegetable, improves serum lipid profiles in healthy young adults: Randomized clinical trial. J Med Food. 2013; 16(3):223-229.

de Mejia EG, Dia VP. The role of nutraceutical proteins and peptides in apoptosis, angiogenesis, and metastasis of cancer cells. Cancer Metastasis Rev. 2010; 29(3):511-528.

Gilliland SE, Nelson CR, Maxwell C. Assimilation of cholesterol by Lactobacillus acidophilus. Appl Environ Microbiol. 1985; 49(2):377381 .

Higashikawa F, Noda M, Awaya T, Ushijima M, Sugiyama M. Reduction of serum lipids by the intake of the extract of garlic fermented with Monascus pilosus: A randomized, double-blind, placebo-controlled clinical trial. Clin Nutr. 2012; 31(2):261-266.

Hill C, Guarner F, Reid G, Gibson GR, Merenstein DJ, Pot B, Morelli L, Canani RB, Flint HJ, Salminen S, Calder PC, Sanders ME. Expert consensus document: The international scientific association for probiotics and prebiotics consensus statement on the scope and appropriate use of the term probiotic. Nat Rev Gastroenterol Hepatol. 2014; 11(8):506-514.

Hur JW, Hyun HH, Pyun YR, Kim TS, Yeo IH, Paik HD. Identification and partial characterization of lacticin $\mathrm{BH}$, a bacteriocin produced by Lactococcus lactis BH5 isolated from Kimchi. J Food Prot. 2000; 63(12):1707-1712.

IARC Working Group. Some naturally occurring substances: food items and constituents, heterocyclic aromatic amines and mycotoxins. IARC monographs on the evaluation of carcinogenic risks to humans. Vol. 56. Lyon: IARC Press; 1993.

Lee HS, Lim WC, Lee SJ, Lee SH, Lee JH, Cho HY. Antiobesity effect of garlic extract fermented by Lactobacillus plantarum BL2 in dietinduced obese mice. J Med Food. 2016; 19(9):823-829.

Lee JK, Jung DW, Kim YJ, Cha SK, Lee MK, Ahn BH, Kwak NS, Oh SW. Growth inhibitory effect of fermented kimchi on food-borne pathogens. Food Sci Biotechnol. 2009; 18(1):12-17.

Li M, Yan YX, Yu QT, Deng Y, Wu DT, Wang Y, Ge YZ, Li SP, Zhao J. Comparison of immunomodulatory effects of fresh garlic and black garlic polysaccharides on RAW 264.7 Macrophages. J Food Sci. 2017; 82(3):765-771.

Lu SH, Camus AM, Tomatis L, Bartsch H. Mutagenicity of extracts of pickled vegetables collected in Linhsien County, a highincidence area for esophageal cancer in Northern China. J Natl Cancer Inst. 1981; 66(1):33-36.

Martins EMF, Ramos AM, Vanzela ESL, Stringheta PC, de Oliveira Pinto CL, Martins JM. Products of vegetable origin: A new alternative for the consumption of probiotic bacteria. Food Res Int. 2013; 51(2):764-770.

Meira SMM, Daroit DJ, Helfer VE, Correa APF, Segalin J, Carro $\mathrm{S}$, Brandelli A. Bioactive peptides in water soluble extract of ovine cheese from southern Brazil and Uruguay. Food Res Int. 2012; 48(1):322-329.

Menconi A, Kallapura G, Latorre JD, Morgan MJ, Pumford NR, Hargis BM, Tellez AG. Identification and characterization of lactic acid bacteria in a commercial probiotic culture. Biosci Microbiota Food Health. 2014; 33(1):25-30.

Mitra S, Chakrabartty PK, Biswas SR. Potential production and preservation of dahi by Lactococcus lactis W8, a nisin-producing strain LWT-Food Sci Technol. 2010; 43(2):337-342.

Natural news. Lowering cholesterol with fermented foods. 2012 http://www.nyrnaturalnews.com/diet-2/2012/11/lowering-cholesterol-withfermented-foods (Accessed on 24.2.2017).

Organic facts, Health benefits of pickles. https://www. organicfacts.net/health-benefits/other/health-benefits-of-pickles.html 
(accessed on 16.02.2017).

Patel A, Prajapati JB, Holst O, Ljungh A. Determining probiotic potential of exopolysaccharide producing LAB isolated from vegetables and traditional Indian fermented food products. Food Biosci. 2014; 5:27-33.

Pattananandecha T, Sirilun S, Duangjitcharoen Y, Sivamaruthi BS, Suwannalert P, Peerajan S, Chaiyasut C. Hydrolyzed inulin alleviates the azoxymethane-induced preneoplastic aberrant crypt foci by altering selected intestinal microbiota in Sprague-Dawley rats. Pharm Biol. 2016; 54(9):1596-1605.

Peerajan S, Chaiyasut C, Sirilun S, Chaiyasut K, Kesika P, Sivamaruthi BS. Enrichment of nutritional value of Phyllanthus emblica fruit juice using the probiotic bacterium, Lactobacillus paracasei HII01 mediated fermentation. Food Sci Technol (Campinas). 2016; 36(1):116123.

Perna A, Intaglietta I, Simonetti A, Gambacorta E. Effect of genetic type and casein halotype on antioxidant activity of yogurts during storage. J Dairy Sci. 2013; 96(6):3435-3441.

Ren JS, Kamangar F, Forman D, Islami F. Pickled food and risk of gastric cancer--a systematic review and meta-analysis of English and Chinese literature. Cancer Epidemiol Biomarkers Prev. 2012; 21(6):905915

Rouhi M, Sohrabvandi S, Mortazavian AM. Probiotic fermented sausage: Viability of probiotic microorganisms and sensory characteristics. Crit Rev Food Sci Nutr. 2013; 53(4):331-348.

Rudel LL, Morris MD. Determination of cholesterol using o-phthalaldehyde. J Lipid Res. 1973; 14((3):364-366.

Samuel Miller Lab, UW, Seattle. 2011. http://miller-lab. net/MillerLab/protocols/general-bacteriology/calculating-growth-rate/ (Accessed on 24.2.2017).

Sanders ME, Marco ML. Food formats for effective delivery of probiotics. Annu Rev Food Sci Technol. 2010; 1:65-85.

Sheehan VM, Ross P, Fitzgerald GF. Assessing the acid tolerance and the technological robustness of probiotic cultures for the fortification of fruit juices. Innov Food Sci Emerg Technol. 2007; 8:279-284.

Shin GH, Kang BC, Jang DJ. Metabolic pathways associated with Kimchi, a traditional Korean food, based on in silico modeling of published data. Genomics Inform. 2016; 14(4):222-229.

Shin MS, Han SK, Ryu JS, Kim KS, Lee WK. Isolation and partial characterization of a bacteriocin produced by Pediococcus pentosaceus K23-2 isolated from Kimchi. J Appl Microbiol. 2008; 105(2):331-339.
Sirilun S, Sivamaruthi BS, Kumar N, Kesika P, Peerajan S, Chaiyasut C. Lactobacillus-fermented plant juice as a potential ingredient in cosmetics: Formulation and assessment of natural mouthwash. Asian J Pharm Clin Res. 2016; 9(Suppl. 3):52-56.

Takezaki T, Gao CM, Ding JH, Liu TK, Li MS, Tajima K. Comparative study of lifestyles of residents in high and low risk areas for gastric cancer in Jiangsu Province, China; with special reference to allium vegetables. J Epidemiol. 1999; 9(5):297-305.

Tamang JP, Shin D-H, Jung S-J, Chae S-W. Functional properties of microorganisms in fermented foods. Front Microbiol. 2016; 7:578.

Todar's online textbook of bacteriology, 2008. http:// textbookofbacteriology.net/growth_3.html (Accessed on 24.02.2017).

Todorov SD, Franco BDGDM. Lactobacillus plantarum: Characterization of the species and application in food production. Food Rev Int. 2010; 26(3):205-229.

Woraharn S, Lailerd N, Sivamaruthi BS, Wangcharoen W, Peerajan S, Sirisattha S, Chaiyasut C. Development of fermented Hericium erinaceus juice with high content of L-glutamine and L-glutamic acid. Int $\mathrm{J}$ Food Sci Technol. 2015; 50:2104-2112.

Woraharn S, Lailerd N, Sivamaruthi BS, Wangcharoen W, Sirisattha S, Peerajan S, Chaiyasut C. Evaluation of factors that influence the L-glutamic and $\gamma$-aminobutyric acid production during Hericium erinaceus fermentation by lactic acid bacteria. CyTa J Food. 2016; 14(1):47-54.

Woraharn S, Lailerd N, Sivamaruthi BS, Wangcharoen W, Sirisattha S, Chaiyasut C. Screening and kinetics of glutaminase and glutamate decarboxylase producing lactic acid bacteria from fermented Thai foods. Food Sci Technol (Campinas). 2014; 34(4):793-799.

Yang CS. Research on esophageal cancer in China: A review. Cancer Res. 1980; 40:2633-2644.

Zhang WX, Xu MS, Wang GH, Wang MY. Quantitative analysis of Roussin red methyl ester in pickled vegetables. Cancer Res. 1983; 43(1):339-341.

How to cite this article:

Chaiyasut C, Kesika P, Sirilun S, Peerajan S, Sivamaruthi BS. Formulation and Evaluation of Lactic Acid Bacteria Fermented Brassica juncea (Mustard Greens) Pickle with Cholesterol Lowering Property. J App Pharm Sci, 2018; 8(04): 033-042. 